\title{
Towards a deposit guarantee insurance in China? A law and economics perspective
}

Citation for published version (APA):

Faure, M. G., \& Hu, J. (2013). Towards a deposit guarantee insurance in China? A law and economics perspective. The Chinese Journal of Comparative Law, 1-33. https://doi.org/10.1093/CJCL/CXT012

Document status and date:

Published: 01/01/2013

DOI:

10.1093/CJCL/CXT012

Document Version:

Publisher's PDF, also known as Version of record

Document license:

Taverne

Please check the document version of this publication:

- A submitted manuscript is the version of the article upon submission and before peer-review. There can be important differences between the submitted version and the official published version of record.

People interested in the research are advised to contact the author for the final version of the publication, or visit the DOI to the publisher's website.

- The final author version and the galley proof are versions of the publication after peer review.

- The final published version features the final layout of the paper including the volume, issue and page numbers.

Link to publication

\footnotetext{
General rights rights.

- You may freely distribute the URL identifying the publication in the public portal. please follow below link for the End User Agreement:

www.umlib.nl/taverne-license

Take down policy

If you believe that this document breaches copyright please contact us at:

repository@maastrichtuniversity.nl

providing details and we will investigate your claim.
}

Copyright and moral rights for the publications made accessible in the public portal are retained by the authors and/or other copyright owners and it is a condition of accessing publications that users recognise and abide by the legal requirements associated with these

- Users may download and print one copy of any publication from the public portal for the purpose of private study or research.

- You may not further distribute the material or use it for any profit-making activity or commercial gain

If the publication is distributed under the terms of Article $25 \mathrm{fa}$ of the Dutch Copyright Act, indicated by the "Taverne" license above, 


\title{
Towards a Deposit Guarantee Insurance in China? A Law and Economics Perspective
}

\author{
Michael Faure* and Jiye $\mathrm{Hu}^{\dagger}$
}

\begin{abstract}
Deposit guarantee insurance has been a very debated topic both in the USA and in Europe. Deposit guarantee insurance is considered to be a highly important mechanism to prevent bank runs and to restore depositor confidence, which is why both in the USA and in Europe during the financial crisis measures were taken to increase the coverage amounts. Interestingly, China is also considering the introduction of a deposit guarantee system. China has indeed known many cases of bank failures recently. Until approximately 20 years ago, this may not have been a big problem in China for the simple reason that all banks were state owned and an implicit guarantee system was provided via the state. However, with privatization of financial markets also occurring in China, bank runs and resulting bank failures have also begun to occur in this country.

Attempts have been taken to introduce a deposit guarantee scheme, but they were put on hold because of the financial crisis. This article looks at the particular situation of China, not only addressing some of the instances of bank failures but also studying the particular design problems that may arise in the Chinese context, in the light of experiences in the USA and Europe. Indeed, from the US and European experience, it is well known that, on the one hand, deposit insurance may have many beneficial aspects (preventing bank runs), but, on the other hand, it may also create problems of its own (in particular, creating a moral hazard on the side of financial institutions and neglect
\end{abstract}

* Michael Faure, Professor of Comparative and International Environmental Law, Maastricht University; Professor of Comparative Private Law and Economics, Erasmus University Rotterdam, both in the Netherlands. Email: michael.faure@maastrichtuniversity.nl; faure@law.eur.nl. This article was written while being haiwai mingshi (distinguished foreign professor) at the Centre for Law and Economics of the China University of Political Science and Law (CUPL). The help of the China Ministry of Education and the Centre of Law and Economics of CUPL is gratefully acknowledged. Both authors are grateful to Wenqing Liao (Maastricht) for research assistance and to Marina Jodogne (Maastricht) for editorial assistance. Jiye Hu, Professor of Law and Economics, China University of Political Science and Law, Beijing, China. Email: jiyeh@cupl.edu.cn. 
on the side of depositors). The article examines how these problems may play out in China and also argues that given the fact that the big five Chinese banks are still state owned introducing risk dependent contributions (which is now advocated in the USA and Europe) may not be appropriate in China.

Keywords: deposit guarantee insurance; financial stability; insurance premium rates; legislation; bailouts; economic analysis; risk differentiation

\section{Introduction}

In the past 33 years, China's gross domestic product (GDP) has doubled every seven years. ${ }^{1}$ After surpassing Italy in 2005, China's economy did not stop this incredible pace: in 2006, its GDP surpassed the United Kingdom; in 2007, it surpassed Germany and, in 2010, Japan. As a result, China has now become the second largest economy in the world. The financial sector has played an important role in China's economic success story. However, until now, China is one of the few countries that does not have an explicit deposit insurance scheme. How to establish such an explicit deposit insurance scheme has become an important topic for both government officials and scholars in China.

Indeed, a major source of worry for many financial institutions and potentially a source of financial crisis is the tendency of consumers to withdraw their savings from a financial institution, often based on rumours concerning the financial situation of a particular bank. A run on the bank occurs when customers/institutions panic and worry that their bank will go bankrupt, losing the funds they have deposited. In such a situation, many customers will withdraw their savings, all within a very narrow time frame (that is, a few days). Although at the beginning, the bank may not have been insolvent, a run on the bank can precipitate the bank into bankruptcy. Indeed, as the run on the bank propagates with more and more customers/institutions losing confidence, at some point the bank's reserve will not be able to meet all of the withdrawal requests and, therefore, the bank will become insolvent.

During the Great Depression, a national run on the bank was characterized by customers physically lining up at their bank to withdraw their savings. With the availability of online transactions, a run on the bank can start with customers/institutions transferring funds to other banks or financial institutions they believe are less likely to default. These kinds of rumours may not even be correct, but spreading these rumours can have a strong self-fulfilling

1 On the causes of China's economic growth, see also Thomas S Ulen, 'The Uneasy Case for Competition Law and Regulation as Decisive Factors in Development: Some Lessons for China' in Michael G Faure and Xinzhu Zhang (eds), Competition Policy and Regulation: Recent Developments in China, the US and Europe (Edward Elgar 2011) 13-44, Thomas S Ulen, 'The Role of Law in Economic Growth and Development' in Michael G Faure and Jan M Smits (eds), Does Law Matter? On Law and Economic Growth (Intersentia 2011) 179-220. 
effect as a result of which a so-called bank run can take place - that is, clients withdrawing all of their savings from a particular financial institution, inevitably leading to its bankruptcy. These kinds of phenomena make the rumours come true, and increasing numbers of people believe that almost all bank run rumours will be realized. In this case, a run on the bank can only be mitigated by certain government actions (that is, the increase of deposit insurance limits by the Federal Deposit Insurance Corporation (FDIC), the re-regulation of banks, increased reserve requirements, monetary bailout, and so on).

One of the systems to prevent a bank run is a deposit guarantee scheme, which is also referred to as deposit insurance. Deposit insurance, the legal system addressing the issue of banking system stability, has become popular around the world and is now common practice. In the 1980s and early 1990s, many countries and regions began to establish a national system of deposit insurance law as an infrastructure to strengthen financial sectors and to build a safety net for banks. A bank safety net could be defined as a set of policy and legal measures that have as their goal the prevention of widespread bank 'disintermediation' and the loss of bank capital. The bank safety net is of course also meant to be a part of a series of policies in law that include the following: (i) the role of the central bank as lender of last resort; (ii) the prudential supervision of banks; and (iii) the deposit guarantee scheme. As a financial safety net, the legal system of deposit insurance is an important part in maintaining the stability of the financial system and protecting the interests of depositors.

It is more particularly in the light of financial crises that policy makers have considered it important to give a strong signal to the market, and in particular to individual depositors, that individual savings are guaranteed up to a specific amount in case the bank goes bankrupt. Hence, this so-called deposit guarantee insurance has as its major goal the prevention of bank runs, and thus it contributes to the financial stability of the financial market. Such a deposit guarantee system was, inter alia, introduced in many European countries following the collapse of the Bank for Credit and Commerce International. As a result, the European Union (EU) introduced a deposit guarantee scheme through Council Directive (EC) 94/19 on deposit-guarantee schemes, which was amended in $2009 .^{2}$

Notwithstanding the undoubtedly positive effects of such a deposit guarantee system, there has also been serious criticism of this system from economists. Some argue that a deposit guarantee system can give financial institutions an incentive to pursue more risky investments. This tendency may in turn lead to a negative impact on their solvency, thus aggravating the problem. This moral hazard problem could be prevented if risk dependent premiums were charged (meaning that financial institutions choosing more risky investment strategies would pay higher contributions to the deposit guarantee system). However, in Europe, only eight countries apply a risk-based

2 Council Directive (EC) 94/19 on deposit-guarantee schemes [1994] OJ L135. 
contribution to their deposit guarantee fund, and the differences range only from a minimum contribution of 75 per cent to a maximum of 140 per cent of the standard amount. ${ }^{3}$ Many countries simply charge a contribution that is only related to the size of the financial institution and not to its investment behaviour. This system may disadvantage larger financial institutions that avoid risky investments and, thus in fact, cross-subsidize newcomers on the market who attract depositors with high interest rates but are a risky investment. Some commentators have therefore wondered whether the cure (of the deposit guarantee system) is perhaps not worse than the disease (risk of bank runs) since the system itself may encourage risky investment and thus contribute to financial crises. ${ }^{4}$ Of course, proposals have been formulated to improve the system-for example, by introducing risk-based contributions or by lowering the coverage level. ${ }^{5}$

China has also been contemplating the introduction of a deposit guarantee system, but so far, it has not yet been implemented for a variety of reasons. The first reason is the earlier-mentioned problem that a guarantee system can provide financial institutions with incentives for risky investments, thus leading to moral hazard. The second reason involves the question of how contributions to the guarantee scheme could be appropriately differentiated, again in order to avoid moral hazard and cross-subsidization. The third reason is the challenge posed by the enormous state-owned banks - they have no incentives to pay an insurance premium since they enjoy a free, substantial implicit guarantee from the central government. Still, the introduction of a deposit guarantee system can be highly important for China in order to guarantee consumer confidence in the growing Chinese economy. Hence, we will argue that the attempts to introduce such a guarantee system in China should certainly be encouraged since otherwise the risks of a bank run (in case of negative rumours concerning a financial institution) are quite realistic.

The goal of this article is to analyse the feasibility of a deposit guarantee insurance system in China. We will do so by analysing some of the reasons why such a system has failed so far in China. We will do so in the light of the experience in Europe, pointing at possible strengths and weaknesses in the current European regulation as a learning tool for China. Our analysis will use a law and economics framework, which will enable us to explain how a deposit guarantee system and its particular institutional structure can provide adequate incentives to all of the stakeholders involved.

Given this goal, the article is set up in the following way. After the introduction, it will first provide a brief overview of the literature. Then it will critically

3 European Commission, Joint Research Centre, Econometrics and Applied Statistics Unit, Possible Models for Risk-Based Contributions to EU Deposit Guarantee Schemes (2009), <http:// ec.europa.eu/internalmarket/bank/guarantee/index.en.htm> accessed 8 May 2013.

4 Hans Groeneveld, 'Towards a Balanced Deposit Guarantee System in Europe' (2009) 419 Banking \& Finance Rev 420.

5 Robert J Dijkstra and Michael G Faure, 'Compensating Victims of Bankrupted Financial Institutions: A Law and Economics Analysis' (2011) 156 J Financial Reg \& Compliance 157. 
review the various attempts to introduce a deposit guarantee system in China, and it will consider the various sources of its failure. Next, the article will describe the deposit guarantee system as it exists in the EU and focus on the functioning of the system in one particular Member State, the Netherlands. Then, it will turn to an economic analysis explaining the potential dangers of a deposit guarantee system, the way in which it affects the incentives of stakeholders, and the remedies that should be introduced to deal with the moral hazards that may result from such an insurance system. These economic observations will be used to formulate a few policy recommendations on the way in which a deposit guarantee system could be successfully introduced in China. The final section provides a conclusion.

\section{A brief literature review}

Economists have given various explanations for the phenomenon of the bank run. Douglas Diamond and Philip Dybvig's 1983 model shows that depositors face privately observed risks that lead to a demand for liquidity. ${ }^{6}$ A depositor's bank run is purely based on some external factors that can be irrelevant for the financial performance of the bank. Just like the effect of a butterfly that can supposedly cause a hurricane, a crisis that originally involves only a single area and a single financial product can become like a hurricane as well, covering the global financial market. The authors have proposed that the government should adopt a 'lender of last resort' system in which the government provides timely emergency loans to banks and, at the same time, establishes a deposit insurance scheme to prevent bank runs from occurring due to asymmetric information. Diamond and Dybvig therefore argue that bank runs can be prevented when deposits are fully and credibly insured. ${ }^{7}$

V.V. Chari and Ravi Jagannathan give another explanation, emphasizing that bank runs may be a reasonable response of depositors when they have observed long 'lines' at the gates of a bank - they correctly infer from the lines that there is a possibility that the bank is about to fail and hence precipitate a bank run. Due to poor performance-related information, depositors panic, triggering a massive run. Extra market constraints such as the suspension of convertibility can prevent bank runs and result in superior allocations. ${ }^{8}$

As Robert Merton has shown, deposit insurance can be viewed as a put option on the value of a bank's assets at a strike price equal to the promised maturity value of its debt. ${ }^{9}$ Robert Cull, Lemma Senbet, and Marco Sorge have

Douglas W Diamond and Philip H Dybvig, 'Bank Runs, Deposit Insurance, and Liquidity' (1983) 91 J Political Economy 401.

7 Ibid 401-19.

8 VV Chari and Ravi Jagannathan, 'Banking Panics, Information and Rational Expectation Equilibrium' (1988) 43 J Finance 749.

9 Robert C Merton, 'An Analytic Derivation of the Cost of Deposit Insurance Loan Guarantees' (1977) 1 J Banking \& Finance 3. 
compared empirical datasets in dozens of countries provided by the World Bank and found that deposit insurance schemes are primarily intended to reduce the risk of systemic failure of banks and hence to stabilize the payments and financial system. ${ }^{10}$ The likelihood that a formal deposit insurance scheme could protect the financial sector is deemed to be significantly higher than what the implicit deposit insurance system could do. An implicit deposit guarantee system is the system whereby a government bails out (larger) financial institutions whenever they get into trouble. This outlook explains the increase in the number of countries offering explicit deposit guarantees from only 20 in 1980 to 87 by the end of 2003. ${ }^{11}$ In the USA where the deposit insurance scheme was first introduced in the world, James Barth found the International Federation of Consulting Engineers had been given adequate powers, and was required to make full and effective use of them, in order to guarantee that an incipient unhealthy condition may be immediately corrected and that inefficient banks may be closed before they reach a state where liquidation would involve losses. ${ }^{12}$

Although the deposit insurance schemes have obviously solved some of the banks' liquidity problems as well as improved the anti-risk ability, the moral hazard resulting from the scheme has greatly limited its effectiveness. Michael Keeley tested the hypothesis that increases in competition cause bank charter values to decline, which in turn causes banks to increase the default risk through increases in asset risk and reductions in capital. ${ }^{13}$ Another problem of the deposit insurance system is that its scope of protection for depositors is too broad. This issue raises the question whether the benefits of this new legal initiative for the country's financial environment are to some extent offset by neglect from the depositors. If the deposit insurance scheme would indeed lead to such an effect, the newly established legal system would just be a transplant in that case, borrowed from another legal system, but would in fact show many defects. Especially in times of financial crisis, there is a danger that deposit insurance would be blamed as being one of the causes of the financial crisis and thus become a 'scapegoat'. From this perspective, deposit insurance would be undesirable since it would lead to risky behaviour by financial institutions. Some countries have even held that abolishing deposit insurance may be the most adequate solution. For example, in 1992, Argentina abolished the system of deposit insurance. However, a financial

10 Robert Cull, Lemma W Senbet, and Marco Sorge, 'The Effect of Deposit Insurance on Financial Debt: A Cross-Country Analysis' (2002) 42 Q Rev Econ \& Finance 673.

11 Asli Demirgü-Kunt, Edward J Kane, and Luc A Laeven, 'Deposit Insurance Design and Implementation: Policy Lessons from Research and Practice' (2006) World Bank Policy Research Working Paper Series no 3969, <http://ssrn.com/abstract=923276> accessed 8 May 2013.

12 James R Barth, 'Deposit Insurance Reform' in United States Senate, Deposit Insurance Reform and Financial Modernization, Hearings before the Committee on Banking, Housing, and Urban Affairs (US Government Printing Office 1990) volume 2, 58-67.

13 Michael C Keeley, 'Deposit Insurance, Risk, and Market Power in Banking' (1990) 80 Am Econ Rev 1183. 
crisis that later took place in Mexico forced Argentina to reintroduce deposit insurance in $1995 .^{14}$

Another important default of deposit insurance schemes is the concomitant issue of moral hazard. G.G. Kaufman argues that deposit insurance schemes will create moral hazard, and he proposes to implement measures to limit the protection of deposits to depositors of banks and financial institutions in order to create incentives to monitor operational risks. ${ }^{15}$ Eugene White even holds that deposit insurance presents 'enormous incentive problems' and would hence also be inappropriate for developing and transition economies. ${ }^{16}$ Therefore, some economists shift the attention to the effectiveness in liquidity problems and financial stability. They suggest strategies such as interbank lending and co-insurance. The key element of these proposals is that when a bank faces a shortage of liquidity it can borrow money through the interbank system or through short-term funds by the central bank, which is the lender of last resort. For example, when a particular impact on the liquidity of banks by other banks may not be strong, other private banks could conclude agreements with the industry. This is a so-called co-insurance approach that could solve the problem that Sudipto Bhattacharya and Douglas Gale uncover, namely that a surplus liquidity on the banking market could in fact lead to illiquid banks. ${ }^{17}$

As a result of the risk prevention capabilities in the interbank market, a shortage of bank liquidity will limit the access to credit within the banking industry, unless the bank can prove that it has a lower risk of default. However, it may be hard for the bank itself to disclose its asset quality characteristics. With the capital markets having been developed, the development of information technology and innovative financial contracts greatly facilitate borrowers' access to capital markets. This access reduces the pre-and post-information asymmetry. When a bank faces a liquidity shock, the bank can more easily liquidate a lower loss, to ease temporary liquidity needs, thus reducing the real value of deposit insurance. Anthony Santomero also holds that depository institutions play a crucial role in an economy by serving as a repository for savings, supporting private sector expenditures, and providing positive returns to liability holders. ${ }^{18}$ However, Santomero argues that deposit insurance also has its own set of problems, being that it encourages risk taking by insured institutions and neglect by depositors. Hence, these potential problems need to be carefully addressed as well.

14 Geoffrey P Miller, ‘Is Deposit Insurance Inevitable? Lessons from Argentina' (1996) 16 Int'l Rev L \& Econ 211.

15 GG Kaufman, 'Bank Failures, Systematic Risk and Bank Regulations' (1996) 16 Cato Journal 17.

16 Eugene M White, 'Deposit Insurance' (1995) World Bank Policy Research Working Paper Series no 1541, <http://ssrn.com/abstract=569205> accessed 8 May 2013.

17 Sudipto Bhattacharya and Douglas Gale, 'Preference Shocks, Liquidity and Central Bank Policy' in WA Barnett and K Singleton (eds), New Approaches to Monetary Economics (Cambridge University Press 1987) 69-88.

18 Anthony M Santomero, 'Deposit Insurance: Do We Need It and Why?' (1997) Wharton Financial Institutions Centre 97, <http://ssrn.com/abstract=33960> accessed 8 May 2013. 
In addition, more recent legal literature has critically reviewed the deposit guarantee system, inter alia, in the way in which it has been implemented in the EU. For example, the senior vice-president of Rabobank Nederland has held that the deposit guarantee system in Europe provides substantially perverse effects. The reason is, so he holds, that it stimulates risky behaviour of depositors and financial institutions and would thus rather undermine financial stability instead of stimulating it. ${ }^{19}$ Moreover, authors in corporate law hold that the deposit guarantee system provides a wrong signal to consumers by signalling that as long as the consumer purchases a financial product on which the deposit guarantee system is applicable there is no risk whatsoever that the customer would lose his money. ${ }^{20} \mathrm{~S}$. Schich also holds that knowing the existence of the deposit guarantee system and its effect on the insured institutions and depositors, financial regulators are thus forced to take a more active role to remedy the potentially perverse effects of the deposit guarantee system. ${ }^{21}$

\section{Deposit guarantee insurance in China: a story of failed attempts}

\section{The steps to developing a deposit guarantee system in China}

Implicit guarantees via bailouts by government

For a long period in China, an implicit deposit insurance scheme has existed based on government credit guarantees provided by China's Central Bank, the People's Bank of China (PBC). When local banks or financial institutions in China become financially distressed or even enter bankruptcy, a joint task force team is usually created to deal with the bank's failure, since the local governments have the responsibility to maintain social stability and banks are constituted by the Central Bank, the local government, and other relevant stakeholders. The task force team (which is mainly made up of members of the Central Bank) will pay the individual debt, which means that the government in fact provides an implicit deposit insurance scheme.

A good example of the problems that arise in the case of an absence of an explicit deposit guarantee system (as is currently the case in China) is provided by the take over of the Hainan Development Bank (HDB). After the Spring Festival of 1998 in the southern China island province of Hainan, a rumour started that HDB would be in financial difficulty. It was a local bank that had been in existence for a mere three years and that was well known for attracting depositors with high interest rates. However, the real estate bubble burst

19 Groeneveld (n 4).

20 HM Vletter-Van Dort, "Ice Save: "If Something Seems too be Good to Be True, It Probably Is" (2009) Ars Aequi 810.

21 S Schich, 'Financial Turbulence: Some Lessons Regarding Deposit Insurance' (2008) 69 OECD Financial Market Trends 55. 
in Hainan in the 1990s and this crisis made it difficult for HDB to recover some of its loans, which were based on security provided by real estate. Local government officials hastened to deny the rumour. Nevertheless, a large number of depositors started to remove both their deposits and their interest from HDB, moving both to China's top five state-owned banks (Industrial and Commercial Bank of China [ICBC], China Construction Bank, Bank of China, Agricultural Bank of China, and Bank of Communications), even though they offered lower interest rates than HDB.

Subsequently, HDB introduced a limit on the weekly amounts that depositors could withdraw and gave priority to ensuring the repayment of individual depositors. The PBC raised an emergency aid of RMB 3.15 billion to rescue HDB. At the same time, it allowed HDB to issue a bond of RMB 0.9 billion in February 1998 and of 0.5 billion in April 1998, but all of the rescue attempts could not save HDB. On 21 June 1998, the PBC announced the closure of HDB and declared that from the date of closure, all assets and liabilities of HDB would be handled by ICBC. ${ }^{22}$ Since ICBC is the largest state-owned commercial bank in China, the announcement by the PBC provided confidence to depositors as a result of which depositors simply transferred their savings to ICBC without causing much social unrest.

The case of Weihai Urban Cooperative Bank (WUCB) is another example. WUCB was established in June 1997. It was formed by five local urban credit cooperatives that had poor management and a lack of effective supervisory mechanisms. After WUCB had been set up and started its activities, a variety of potential risks began to materialize - a substantial decline in the deposits took place and some sub-branches were unable to pay the debts due in March 1998. The triggering wave of large-scale runs began: withdrawing depositors crowded outside the banks, culminating in up to 200 visitors per day in one branch. The Weihai municipal government was forced to take urgent stringent measures and to mobilize the police to the outlets of the banks to maintain public order. The PBC also conducted on-site monitoring. The local government replaced non-performing assets of RMB 800 million with fiscal revenues and sold 58 per cent of the shares of WUCB to a local state-owned enterprise. Finally, the PBC and the local government spent a total amount of RMB 1.8 billion to save the bank, they changed its name to the Weihai City Commercial Bank in October 1998. ${ }^{23}$

From 1997 to 1998, the PBC closed 42 problematic depository institutions: one commercial bank (that is, the earlier-mentioned HDB), 23 urban credit cooperatives, and 18 rural credit cooperatives. In addition, the PBC closed three trust and investment companies (China Agricultural Trust and Investment Corporation, China Venture Investment Corporation, and Guangdong

22 Hua Liu, ‘Enlightenment of Hainan Development Bank's Close Down’ (2004) 2 The Banker 123 [in Chinese].

23 Mingli $\mathrm{Wu}$ and others, 'The Dynamic Improvement of Government Behaviour and Regulation: A Case Study of Banking Risk Resolution in Weihai City Commercial Bank' (2003) 3 J Finance 105 [in Chinese]. 
International Trust and Investment Corporation [GITIC]). The par value of assets of all of the closed financial institutions totalled RMB 108.8 billion. $^{24}$ of these cases, the GITIC case was probably the most important one. In October 1998, GITIC incurred heavy losses and could not meet its maturing debts. The central bank announced the closure of this financial institution. However, the liquidation, which was led by a well-known international accounting firm, found that GITIC was seriously insolvent. In January 1999, GITIC applied for bankruptcy. ${ }^{25}$ This was the first time a financial institution had gone bankrupt in China.

\section{Becoming increasingly expensive and debated}

Bank runs on small credit cooperatives occur more frequently at the provincial and city level. For example, in Shantou city of Guangdong province, 13 local urban credit cooperatives agreed to merge with the approval of the PBC to establish the Shantou City Commercial Bank (SCCB) in 1997. They solicited depositors and attracted them with high interest rates. However, a misappropriation of funds took place as well as off-the-book loans and a series of operational problems. The result was that SCCB could not pay the debt of approximately RMB 1.5 billion to its depositors, which included the Shantou City Finance Bureau and other departments of the local government. The loan loss rate climbed as high as 32.23 per cent. After effectively operating for only four years, the SCCB was closed down by the PBC in August 2001. ${ }^{26}$

In Zhejiang province, after depositors realized that the chairman of the Huangyan Xunda Urban Credit Cooperative (ZXUCC) had speculated with RMB 60 million of credit capital, they rushed to the credit cooperative to withdraw their money. The provincial government created an emergency fund of RMB 45 million, and the PBC also injected a deposit reserve into the credit cooperative. In the end, most of the individual depositors' savings and interests were paid back, while only the deposits of some non-individual customers went unpaid. These events led to a heated debate in financial circles. ${ }^{27}$ The result of this debate was the unanimous conclusion that especially in order to deal with risks posed by small- and medium-sized financial institutions it was

24 Shiyu Liu, 'China's Experience in Small and Medium Financial Institution Resolution' (1999) Bank for International Settlements, <https://www.bis.org/publ/plcy07t.pdf $>$ accessed 8 May 2013.

25 For an analysis of the cases, see the report by Xie Ping who was at the time the head of the research department of the People's Bank of China. Xie Ping, 'Bank Restructuring in China' (1999) Bank for International Settlements, <http://www.bis.org/publ/plcy06c.pdf > accessed 8 May 2013.

26 Guotai Chi and others, 'Warning Model of Operating Risk for Commercial Banks and Its Empirical Study' (2009) 24 J Systems Engineering 408 [in Chinese].

27 Guohua Ying, 'Moth of Huangyan Xunda Urban Credit Cooperative' (2003) 2 China Anti-Counterfeiting 26 [in Chinese]. 
urgently necessary to create a deposit insurance scheme. The idea was that a deposit insurance scheme could remove the worry from depositors concerning the potential loss of their savings. Thus, deposit insurance could limit damage due to bank runs, reduce the adverse social impacts of bankruptcy of financial institutions, and maintain the stability of the financial system.

From the cases of HDB, WUCB, and ZXUCC, we can see that implicit deposit government guarantees have played an important role in maintaining social stability and protecting the individual depositors' interest. However, the disadvantages of the current system also become increasingly clear. First, the government has absorbed a heavy cost in paying for the losses of these banks and financial institutions. These losses will inevitably be passed on to the taxpayers, while only the depositors of the institution that is bailed out will gain any benefit. This kind of implicit deposit insurance scheme, thus, creates a negative redistribution to the disadvantage of ordinary taxpayers. Second, as the lender of last resort, the central bank has the implicit duty to deal with the consequences of the financial crisis, but commercial banks, which have no responsibility in this matter, can receive high earnings from the risky investments in which they engage. Such a situation creates the moral hazard to which we referred in the introduction. Third, the current implicit deposit insurance scheme prioritizes individual depositors - non-individual depositors will suffer a loss in the case that the financial institution closes and they will hence suffer in the case that the commercial banks fail.

\section{The initial steps}

Policy makers in China have also realized many disadvantages in the current implicit deposit guarantee system based on government guarantees. Thus, the idea rose to create explicit deposit insurance. The first governmental document can be traced back to 1993. The State Council's Decision on the Reform of the Financial System (State Council Documentary No. 91, 1993) proposed to establish a national deposit insurance fund, and it was the first formal announcement of the idea to construct an explicit deposit insurance scheme in China.

In 1997, the national financial conference made the announcement of building a national deposit insurance scheme for small- and medium-sized financial institutions. In the same year, the PBC set up a special task force team to undertake research concerning the necessary framework for an explicit deposit insurance scheme in China. After several years of study, the task force team published a report entitled Some Thinking on Building up a Deposit Insurance Scheme in China in 2003. The report pointed out that six issues had to be solved when introducing an explicit deposit insurance scheme: (i) evaluating the timing and steps to take to change from an implicit to an explicit deposit insurance scheme; (ii) establishing the organizational framework for a deposit insurance scheme; (iii) dealing with the moral hazards that may result from a deposit insurance scheme; (iv) determining the reasonable scope and limits of the awarded protection; (v) collecting and building up a deposit 
insurance fund; and (vi) developing a market exit mechanism for failed commercial banks. ${ }^{28}$

In April 2004, the Deposit Insurance Section was set up under the Department of Financial Stability in the PBC. The new governmental office did some preparatory work to promote the establishment of an explicit deposit insurance scheme by drafting the legislation necessary for such a scheme. In December 2004, a draft of the Deposit Insurance Regulation was presented to the relevant ministerial departments. Government officials, scholars, and legislators were working together to prepare a draft law for China's deposit insurance. In March 2005, the State Council principally approved the initial proposal to establish a deposit insurance scheme, prepared by the Department of Financial Stability of the PBC. By the end of 2006, the PBC published its second China Financial Stability Report, in which the PBC pointed out that it would speed up the development of a deposit insurance scheme and promote a sound long-term risk management mechanism. ${ }^{29}$ The report deals with the roles of deposit insurance agencies, membership in the deposit insurance scheme, the source of the deposit insurance fund, the maximum payment limits, the institutional arrangements, and other issues.

On 2 August 2007, the chairman of the US FDIC, Sheila Bair, met Zhou Xiaochuan, governor of the PBC. It was mentioned that with the commercial banks reform progressing smoothly, the financial industry continuing to open up, and the stable macro-economic situation, the implementation of a deposit insurance system could be implemented at a low cost. The relevant state departments began to undertake legislative work concerning the Deposit Insurance Act. $^{30}$ In March 2008, Prime Minister Wen Jiabao announced in his report to the National People's Congress that China would establish a deposit insurance scheme in the near future. ${ }^{31}$ However, because of the international financial crises in the same year, the establishment of the deposit insurance scheme was delayed. Finally, in August 2009, the PBC, in combination with the China Banking Regulatory Committee and other concerned organizations, submitted a new implementation deposit insurance proposal to the State Council, China's central government. In its most recent 2011 China Financial Stability Report, the $\mathrm{PBC}$ published its point of view concerning the deposit insurance scheme:

Currently, due to the absence of a deposit insurance scheme in China, there is a moral hazard that is related to a reliance on the creditworthiness of government. Facing the increasingly complex international and domestic financial situation, a fully and effectively

28 Task Force Team of People's Bank of China, 'Some Thinking on Building up a Deposit Insurance System in China' (2003) 5 China Finance 17 [in Chinese].

29 People's Bank of China (PBC), China Financial Stability Report 2006 (China Financial Publishing House (2006) <http://www.pbc.gov.cn/publish/english/959/1958/19584/19584..html> accessed 8 May 2013.

30 Yan Song and Juanjuan Niu, 'Zhou Xiaochuan: It Is Ripe for Establishing a Deposit Insurance System' Chinese Financial News (Beijing, 3 August 2007) [in Chinese].

31 Jiabao Wen, Report on the Work of the Government (First Session of the Eleventh National People's Congress, Beijing, 5 March 2008), <http://www.npc.gov.cn/englishnpc/Special.11.3/2010-03/ 03/content.1547655.htm> accessed 8 May 2013. 
functioning deposit insurance scheme with appropriate powers and responsibilities should be established in a timely manner in order to exert a positive impact on protecting depositor interests, safeguarding public confidence and stability and improving a market-based exit mechanism for financial institutions. ${ }^{32}$

From this brief historical overview, it appears that China has had an implicit deposit guarantee system for a long time, which has its historical roots in the large role played by the PBC. However, the costs of this implicit deposit guarantee system appear to be quite significant. At the same time, this system has also created various potential risks, particularly in regard to moral hazards and negative redistribution. In considering various incidents, discussed earlier, these shortcomings become increasingly clear. The 2007 financial crisis, which spread from the USA to a global financial crisis once more underscored the importance of having an explicit deposit insurance scheme in order to maintain the stability of the financial system. In 2012, Prime Minister Wen Jiabao reiterated the intention of the Chinese government to set up a sound mechanism for preventing systemic financial risks and for coordinating financial oversight and supervision to strengthen China's ability to withstand risks. $^{33}$

\section{The goals of a deposit insurance scheme in China}

The brief historical overview in the previous section shows that after 20 years of discussion and preparation, there is now a consensus among government officials and scholars in China that an explicit deposit insurance scheme has to be established. This scheme should reach specific goals that will now be outlined.

\section{Protecting the interests of small depositors}

Saving money with a financial institution has always been the preferred method of financial investment in China. According to the Chinese State Statistics Bureau, the savings rate in China has remained over 40 per cent of personal disposable income in the past 30 years. The savings deposits of Chinese urban and rural residents in 2001 were only RMB 7.3762 trillion (approximately US \$0.9 trillion). This amount increased to RMB 30.3303 trillion (approximately US $\$ 4.5$ trillion) in 2010. In other words, in 10 years, the amount of savings has increased 4.11 times. The annual growth rate is over 17 per cent, and the savings rate in 2010 reached as high as 46 per cent,

32 PBC, China Financial Stability Report 2011 (China Financial Publishing House 2011) 143, $<$ http://www.pbc.gov.cn/image.public/UserFiles/english/upload/File/China\%20Financial\%20 Stability\%20Report\%202011.pdf> accessed 8 May 2013.

33 Jiabao Wen, Report on the Work of the Government (Fifth Session of the Eleventh National People's Congress, Beijing, 5 March 2012), <http://www.china.org.cn/learning.english/2012-03/14/con tent.24894055.7.htm> accessed 8 May 2013. 
which is substantially higher than in most Western countries, even including Japan, which is traditionally considered to be a country with a high savings rate. $^{34}$

There are several reasons for the high savings rates in China. First, given the limited coverage by the social security system (social healthcare insurance, pension insurance, and so on), increasing house prices, and increasing expenses for the children's education, the financial assets of China's low-income households are relatively limited. Thus, savings deposits for many Chinese constitute the basic living guarantee for the future. Second, with the current rapid economic development, the income of Chinese residents has also increased. For example, from 1991 to 1999, China's GDP increased 10.4 per cent per annum on average, while the disposable income of urban residents and the net income of rural residents increased 6.9 per cent and 4.8 per cent respectively. Under the influence of these factors, residents' income nationally increased at an annual average rate of 7.1 per cent. ${ }^{35}$ Due to limited alternative investment channels, a high number of resident assets still consists of deposits. Therefore, one can notice that among all possible financial instruments, deposits still play the most important role for ordinary Chinese residents.

The structure of deposits in China is another very important element. According to the 2011 China Private Wealth Report, China's overall individual investable assets totalled RMB 62 trillion in 2010. ${ }^{36}$ This amount constituted a 19 per cent increase since 2009. By the end of 2010, there were 503,000 Chinese with a high net worth of at least RMB 10 million in investable assets. Their average investable assets per capita were approximately RMB 30 million. The aggregate investable assets for all high net worth individuals equalled RMB 15 trillion and accounted for 24.2 per cent of the total investable assets. By the end of 2010, the total population of China was 1.34 billion, which means that only 0.37 per cent of the population accounted for 24.2 per cent of all investable assets, while the other 99.63 per cent of small deposit accounts are made up of the vast majority of household savings deposits in China.

Small deposits are also essential for satisfying the basic needs for the vast majority of low-income depositors. These small depositors do not have sufficient financial resources and investment skills. For them, it is difficult to make a correct evaluation of the asset quality of banks. Therefore, it could be considered unfair to let small depositors bear the losses of bank failures that they are unable to evaluate. Protecting these small depositors via a deposit insurance scheme could therefore contribute to social stability. The deposit

34 All data come from Chinese State Statistics Bureau's official website at: <http://www.stats.gov. $\mathrm{cn}>$ accessed 8 May 2013.

35 Wen Li, 'The Income and Consumption of Chinese Residents since Reform and Opening Up' (2007), <http://www.iccs.cn/contents/471/9034.html> accessed 8 May 2013.

36 China Merchant Bank and Bain and Company, 2011 China Private Wealth Report-China's Private Banking Industry: Competition Is Getting Fierce' (2011), <http://www.bain.com/Images/ 2011_China.wealth.managementreport.pdf> accessed 8 May 2013. 
insurance scheme could protect the interests of small depositors and improve the living standard for many of these low income depositors.

\section{Preventing a banking crisis}

Since China became the 143rd member of the World Trade Organization (WTO) at Doha on 10 November 2001, after five years of protecting its banking and insurance sectors, China has the obligation, under the WTO rules, to move towards a market economy and open up its financial market. ${ }^{37}$ A deposit insurance scheme could effectively protect the financial system against a credit crisis by avoiding the insolvency of banks and thus maintaining financial stability. Moreover, China has the obligation to reform its financial system towards a market-oriented model of equal competition in the financial market. An important element of the reform of the banking system in China is to promote fair competition and hence prevent monopolistic behaviour. In this respect, there is a problem in China since, as was already mentioned earlier, an important characteristic of the top five banks is that they are all state controlled. Since China does not have floating interest rates between commercial banks, many depositors may believe that the top five state-controlled banks are more trustworthy. Thus, depositors may have the tendency to deposit their savings with these top five banks. Depositors may consider that the state-controlled banks will enjoy an implicit guarantee from government in case of financial difficulties. This preference of the market for state-controlled banks may be to the disadvantage of newly established private commercial banks, urban and rural credit cooperatives, and other non-state-owned banking institutions.

An explicit deposit insurance scheme may help to change this situation and hence to guarantee fair competition between the top five state-controlled banks and other financial institutions. This competition will of course benefit consumers who will obtain lower costs and better services. By establishing a legal framework for deposit insurance, regulatory authorities could at the same time regulate the market exit of certain financial institutions, which could improve the overall efficiency of the financial market. Today, the top five state-controlled banks were all listed companies in the past eight years-four of them were even listed on the international stock market. Thus, they must earn money for their shareholders, including their foreign shareholders. An implicit deposit insurance scheme has the disadvantage that it uses ordinary tax payers' money to subsidize shareholders and depositors from commercial banks. An explicit deposit insurance scheme, on the other hand, makes financial institutions pay an insurance premium as a result of which small- and medium-sized financial institutions can compete more easily with the top five in China. This competition could increase the efficiency of financial institutions, but, at the same time, it could also increase financial risks and thus the

37 C Satapathy, 'China’s Membership of WTO: A Few Impressions' (2002) 37 Econ \& Pol Weekly 2208. 
risk of possible bank runs. Again, an explicit deposit insurance scheme can thus not only regulate financial institutions, but it could also warn banks in case of poor management. At the same time, the deposit insurance scheme could also prevent well-performing banks from suffering from a bank run in a systemic banking crisis. Ideally, a deposit insurance scheme could benefit well-managed banks and lead to the exit of poorly performing banks.

\section{Establishing an effective market exit mechanism}

The case of HDB, discussed earlier, showed that the government-based implicit insurance scheme has a high cost when a commercial bank exits the market. A deposit insurance scheme could provide a legal framework with an exit mechanism for financial institutions, which could protect the interests of depositors and maintain the stability of the financial system. Currently, the creation of a financial institution is regulated by the $\mathrm{PBC}$ and other regulatory bodies. However, in the case of the failure of a financial institution, there are no adequate market exit mechanisms. De facto, local governments often play a key role in maintaining social stability, which often amounts to a bailing out by local government. In a well-functioning market economy, a (financial) enterprise should have the possibility of failing and exiting the market - in this respect, a bank should not constitute an exception. Thus, participating in a deposit insurance scheme should not only provide a guarantee for the financial institution itself but also for the depositors.

A deposit insurance scheme could collect a significant amount of premiums to rescue financial institutions in case of difficulty. An insurance fund could be used in a rational and timely way to minimize the damage when a bank fails. Experience in the USA and Europe has shown that a deposit insurance agency is important not only to provide liquidity for a bank ${ }^{38}$ but also to monitor the compliance of banks. ${ }^{39}$ More importantly, since the deposit insurance agency itself is the largest creditor of a failed bank, it could enable financial institutions to exit the market in a smooth way. For example, in the case of Indymac Bank in 2008, the Office of Thrift Supervision (OTS) determined that within the institutional framework at that time Indymac was unlikely to be able to meet its continuing depositors' demands in the normal course of business and was therefore in an unsafe and unsound condition, so the OTS announced Indymac's closure late on 11 July 2008 and transferred operations to the FDIC. The FDIC's proposal for foreclosure avoidance was a loss-sharing

38 The experience in Europe will be discussed later in this article in the fourth section.

39 Grossman showed that newly insured thrifts undertook less risk than their uninsured counterparts, possibly because of screening by deposit insurance authorities. However, a moral hazard emerged gradually as a result of which he concludes that effective regulation and supervision remain important in maintaining financial stability. Richard S Grossman, 'Deposit Insurance, Regulation, and Moral Hazard in the Thrift Industry: Evidence from the 1930s' (1992) 82 Am Econ Rev 800. 
insurance plan, under which the federal government could make good on half of the loss suffered by a lender that modified a loan according to the Indymac protocol but later saw the loan go into default and foreclosure. ${ }^{40}$

\section{Reducing the cost of bank failure}

After the Asian financial crisis of 1998, the Chinese government decided to issue RMB 270 billion special treasury bonds to increase the capital ratio for the top four state-owned banks. Since 1999, these top four banks have peeled off a total of RMB 1.3939 trillion in bad assets. These assets comprise the total costs resulting from the failure of the banks. In November 2005, the PBC published the first China Financial Stability Report and held that the state paid a huge number of financial and human resources to resolve the financial risks and maintain the financial system stability' ${ }^{41}$ The report did not give the specific amount, but, according to Wenpeng Lu's calculation in 2003, the public finance invested into the reconstruction costs of the Chinese banking system equal approximately RMB 1.489 trillion, accounting for 30.2 per cent of GDP in $1999 .^{42}$

Although the financial costs resulting from the reconstruction of the banking system may be debated, there is no doubt that the current implicit deposit guarantee system leads to staggering costs. Given the important growth of China's banking industry, it can be predicted that in the absence of a deposit insurance scheme, the next financial crisis in China would really lead to huge reconstruction costs for the banking system. Hence, the argument goes that it seems wiser to develop an explicit deposit insurance scheme now that may mitigate the impact of a future financial crisis.

\section{Maturing the financial legal system}

Currently in China, there is neither general, nor specific, legislation dealing with bank insolvency or corporate restructuring. In the case of insolvency only, the bankruptcy procedure that follows the Enterprise Bankruptcy Law of the People's Republic of China (PRC) (which entered into force on 1 June 2007) and the Civil Procedure Law of PRC (which was amended on 1 April 2008) could apply. ${ }^{43}$ Some other laws may play a role such as the Law of the PRC on the People's Bank of China, the Commercial Bank Law of the PRC, the

40 Phillip Swagel, 'The Financial Crisis: An Inside View' (2009) Brookings Papers Econ Activity 1.

41 China Financial Stability Report, 2005. See <http://www.pbc.gov.cn/publish/english/959/1958/ 19583/19583..html > accessed 23 May 2013.

42 Wenpeng Lu, 'Research on Government Guarantees and Fiscal Cost of China's Economic Transition' PhD thesis, Fudan University, Shanghai (2003).

43 Enterprise Bankruptcy Law of the People's Republic of China (2007); Civil Procedure Law of People's Republic of China (2008). 
Banking Supervision Law of the PRC, and the Companies Law of the PRC. ${ }^{44}$ In addition, the State Council and financial regulators issued a number of regulations on bank insolvency, such as the Regulations on Closure of Financial Institutions (State Council Decree No. 324, 2001). These laws and regulations have provided for some general rules that apply in case of the bankruptcy of a bank. However, they fail to provide an adequate protection of the interests of depositors or an adequate exist mechanism for banks in financial distress. Legislation concerning deposit insurance could improve China's banking legislation system, as a result of which China would be more in line with international standards.

Since the insolvency of a bank has a few specific features that are different from the bankruptcy of an ordinary commercial company, most developed countries have developed specific rules dealing with the insolvency of financial institutions. For example in the USA, bank failures are regulated by the 1933 Federal Deposit Insurance Act of 1933 as well as by a procedural amendment that took place in the 1971 Federal Deposit Insurance Act. ${ }^{45}$ The 1991 Federal Deposit Insurance Corporation Improvement Act allowed the FDIC to borrow directly from the Treasury department and mandated that the FDIC resolve failed banks using the least-costly method available. ${ }^{46}$ It also ordered the FDIC to assess insurance premiums according to risk and created new capital requirements. ${ }^{47}$

In China, there now is an urgent need to establish a specific law dealing with the insolvency of banks. This law should replace the many scattered laws now dealing with bank failures and will enable the government to develop uniform standards applicable in case of a bankruptcy, enabling the liquidation of a financial institution in case of bankruptcy in an orderly fashion. Not only does China currently lack a decent bankruptcy law for banks, but its property law is also (notwithstanding many recent changes) not sufficiently developed. Since there are no rules on how the government could act, for example, as a lender of last resort, rules are also failing in regard to the allocation of assets of non-performing banks. Again, lacking the financial support from a deposit insurance scheme, the government will have to intervene and use tax payers' money. In sum, the introduction of a deposit insurance scheme

44 Law of the People's Republic of China on the People's Bank of China (1995); Commercial Bank Law of the People's Republic of China (1995); Banking Supervision Law of the People's Republic of China (2003); Companies Law of the People's Republic of China (1994).

45 Insurance is provided through the Federal Deposit Insurance Corporation (FDIC), which insures deposits in banks for at least US \$250,000. It was created in 1933 in response to the thousands of bank failures that occurred in the 1920s and early 1930s. The FDIC claims on its website (since the start of FDIC insurance on 1 January 1934) that no depositor has lost a single cent of insured funds as a result of a failure. Federal Deposit Insurance Act Pub L 81-797, 64 Stat 873.

46 Federal Deposit Insurance Corporation Improvement Act 12 USC 1811.

47 On the importance of charging risk dependent premiums, see White (n 16). On the reform of deposit insurance in the USA, see John L Douglas, 'Deposit Insurance Reform' (1992) 27 Wake Forest L Rev 11. 
in China would bring the financial legislation to maturity, protecting the consumers' rights, increasing the efficiency of the financial system, and bringing it in line with international standards.

\section{The deposit guarantee scheme in the EU}

\section{Goals of the directives}

On 30 May 1994, Counsel Directive (EC) 94/19 on deposit guarantee schemes was promulgated. ${ }^{48}$ The preamble to the Directive clearly states that the goal of the Directive is to provide a harmonized minimum level of deposit protection wherever deposits are located in the Community. Developing these rules was important for the EU in order to complete the single banking market. The preamble also holds that there are undoubtedly costs for a bank to participate in a guarantee scheme, but these costs bear no relation to the costs that would result from a massive withdrawal of bank deposits not only from a credit institution in difficulties, but also from healthy institutions following a loss of depositor confidence in the soundness of the banking system. The preamble therefore clearly shows that the goal of Directive 94/19 was to provide a harmonized system of deposit guarantee in order to avoid bank runs. After bankruptcies of various financial institutions in the 1960s and 1970s, many European countries had already established explicit deposit guarantee systems, but the EU felt that it was important to have a more or less harmonized system for the completion of the single banking market.

Interestingly, Directive 94/19 revealed, on the one hand, the necessity to prescribe a minimum guarantee level (to have some degree of harmonization in the (then) EU), but, on the other hand, the drafters also realized that complete protection for all deposits could lead to a moral hazard on the side of financial institutions. In the preamble of the Directive, this danger is formulated in the following way:

Whereas, on the one hand, the minimum guarantee level prescribed in this Directive should not leave too great a proportion of deposits without protection in the interest both of consumer protection and of the stability of the financial system; whereas, on the other hand, it would not be appropriate to impose throughout the Community a level of protection which might in certain cases have the effect of encouraging the unsound management of credit institutions; whereas the cost of funding schemes should be taken into account; whereas it would appear reasonable to set the harmonized minimum guarantee level at ECU 20.000.

Therefore, Directive 94/19 introduced a mandatory deposit guarantee scheme. Article 3 provided that no credit institution authorized in a Member State would be allowed to take a deposit unless it was a member of such a scheme. Article 10 of the Directive holds that deposit guarantee schemes shall

48 Directive 94/19 (n 2). 
be in a position to pay duly verified claims by depositors in respect of unavailable deposits within three months after the relevant competent authorities have determined that the credit institution concerned appears to be unable to repay the deposit and to have no current prospect of being able to do so.

Counsel Directive (EC) 2009/14 on deposit guarantee schemes as regards the coverage and the payout delay has amended Directive 94/19. ${ }^{49}$ The goal of this new Directive is to amend the previous Directive with respect to two important points, the coverage level and the payout delay. The most important reason to issue a new Directive in 2009 was that after the financial crisis of 2008 it had become clear that the previous directive of 1994 provided minimum coverage levels that were too low and that had to be adapted. Another important amendment in Directive 2009/14 was that it was held that the payout delay of three months currently provided for in the (old) Directive 94/ 19 runs counter to the need to maintain depositor confidence and does not meet their needs. After all, Directive 94/19 had already installed a deposit guarantee system, but it was apparently not able to sufficiently restore depositor confidence and prevent bank runs. Therefore, the new directive stipulates that the payout delay should be reduced to a period of 20 working days.

\section{The minimum coverage level}

In Article 7, Directive 94/19 provides a minimum coverage level of at least $€ 20,000$. According to Article 13, Member States have to bring their laws into conformity with the Directive by 1 July 1995. However, Article 7(1) provides that in Member States in which, when this Directive was adopted, deposits are not covered, up to $€ 20,000$ would apply as the maximum amount laid down in their national guarantee schemes, provided that such amount was not less than $€ 15,000$. This transitional period could be valid until 31 December 1999 . The limit applies to the aggregate deposits placed with the same credit institution, irrespective of the number of deposits. Hence, when a person makes various deposits with Bank A, the maximum amount covered by the deposit guarantee scheme (of $€ 15,000$ or $€ 20,000$ ) would apply. If, on the other hand, the same person also has made deposits with banks $\mathrm{B}$ and $\mathrm{C}$, a similar amount would apply as well.

A study done by the European Commission on the minimum guarantee level showed that there are considerable differences between the Member States. Moreover, the study also held that by 2004 the average guarantee level had decreased overtime in real terms, essentially due to the erosive effects of inflation in those countries that had a guarantee level higher than the harmonized minimum in 1995. The study therefore concluded that the original goal of the Directive was not to 'leave too great a proportion of deposits without protection in the interest both of consumer protection and of the stability of the financial

49 Counsel Directive (EC) 2009/14 on deposit-guarantee schemes as regards the coverage and the payout delay [2009] OJ L68/3. 
system', such a goal could not be achieved any longer across all Member States where there was great variation in the ratio between the insured and insurable deposits. Moreover, in some Member States, so the study concluded, almost all insurable deposits were de facto subject to deposit insurance as a result of which the guarantee level could encourage unsound management of credit institutions, which the Directive precisely wanted to avoid. As a result, the report proposed amending the original Directive 94/19.

The new Directive was obviously triggered by the financial crisis that started in 2008. This crisis led to the already mentioned new Directive 2009/14, which increased the protection for individuals to an amount of $€ 50,000$. The preamble to Directive 2009/14 holds:

The current minimum coverage level provided for in Directive 94/19/EC is set at Euro 20.000 with the option for Member States to determine higher coverage. However, this has proved not to be adequate for a large number of deposits in the Community. In order to maintain depositor confidence and attain greater stability on the financial markets, the minimum coverage level should therefore be increased to Euro 50.000. By 31 December 2010, coverage for the aggregate deposits of each depositor should be set at Euro 100.000, unless a Commission impact assessment, submitted by the European Parliament and the Council by 31 December 2009, concludes that such an increase and such harmonization are inappropriate and are not financially viable for all Member States in order to ensure consumer protection and financial stability in the Community and to avoid distortions of competition between Member States. ${ }^{50}$

An example of how this scheme has been implemented in a Member State can be provided by looking at the system in the Netherlands. Initially, the Dutch deposit guarantee scheme guaranteed an amount of $€ 20,000$. In 2005, this amount was increased to $€ 40,000$. Of this amount, $€ 20,000$ was guaranteed for 100 per cent, while depositors faced a risk of 10 per cent on the next $€ 20,000$. As a consequence, depositors could only receive compensation for a maximum of $€ 38,000$ if their deposits exceeded the amount of $€ 40,000$. This kind of coverage is referred to as co-insurance. As a result of a legislative change (following the financial crisis) in October 2008, the guaranteed amount rose from $€ 40,000$ to $€ 100,000$ without any co-insurance. ${ }^{51}$ This amount was in excess of the prescribed level of coverage that was set by the European Commission for 2010 at $€ 50,000$, but it was in line with the years to follow. ${ }^{52}$

50 Consideration (3) preceding Directive 2009/14 (n 49).

51 On 7 October 2008, the Dutch minister of finance announced the new guarantee limits. See also the memorandum of the Dutch Ministry of Finance (Doc FM/2008-2610M) in which the current deposit guarantee limits of the European Union (EU) are expressed.

52 Just to compare: the amounts in the USA are substantially larger. Savings, checking, and other deposit accounts are generally insured to US \$250,000 per depositor in each bank or thrift the FDIC insures. This amount of US \$250,000 per depositor applies until 31 December 2013. On 1 January 2014, the standard insurance amount will return to US $\$ 100,000$ per depositor (see the website of the FDIC <http://www.fdic.gov/> accessed 8 May 2013). 


\section{Financing}

An important question is obviously how the deposit guarantee scheme, which was created in Europe, is financed. Strikingly, the original Directive 94/14 was silent on the point of financing. The new Directive 2009/14 states:

A report to be submitted to the European Parliament and to the Council by the Commission should analyse all related issues such as set-offs and counter claims, the determination of contributions to schemes, the scope of product and depositors covered, the effectiveness of cross-border cooperation between deposit-guarantee schemes and the link between deposit guarantee schemes and alternative means for reimbursing depositors, such as emergency payout mechanisms. For the purpose of that report, Member States should collect the relevant data and submit them to the Commission on request. ${ }^{53}$

Interestingly, Article 7 of Directive 2009/14 explicitly provides in the replaced Article 12(1)(c) that the Commission shall submit a report by 31 December 2009 and that it shall also examine 'possible models for introducing risk-based contributions'. Meanwhile, important steps have been set up in that respect. A report was filed by the Econometrics and Applied Statistics Unit at the Joint Research Centre concerning possible models for risk-based contributions to EU deposit guarantee schemes. ${ }^{54}$ This report led to a legislative proposal for a thorough revision of Directive $94 / 19 .^{55}$ The proposal holds in a new Article 11 that risk-based contributions will be introduced in deposit guarantee schemes, such that a differentiation can take place between the levels of contribution paid by the least and most risky banks from 75 per cent to 200 per cent of the standard amount, respectively. ${ }^{56}$ This contribution would be incorporated in a newly drafted Article 11, which holds that the determination of the degree of risk incurred and the calculation of contributions would be based on specific elements referred to in Annexes I and II. These annexes provide some core indicators related, inter alia, to the asset quality, capital adequacy, profitability, and liquidity of the particular financial institution. ${ }^{57}$

In general, a deposit guarantee system can be funded in three ways, namely $e x$ ante and ex post as well as a combination of ex ante and ex post mechanisms. ${ }^{58}$ Ex ante funding requires the accumulation and maintenance of a fund to cover deposit insurance claims and related expenses prior to a failure actually occurring. It is funded by its members through contributions, insurance premiums, and other means. ${ }^{59}$ Ex post funding occurs after the bankruptcy of

53 Consideration (5) preceding Directive 2009/14 (n 49).

54 European Commission, Joint Research Centre (n 3).

55 European Commission, 'Review of Directive 94/19/EC on Deposit Guarantee Schemes' Doc COM (2010) 369.

56 Ibid 8.

57 Ibid 47.

58 International Association of Deposit Insurers (IADI), Funding of Deposit Insurance Systems, Guidance Paper from the Research and Guidance Committee (2009), <http://www.iadi.org/ docs/Funding\%20Final\%20Guidance\%20Paper\%206_May_2009.pdf> accessed 8 May 2013.

IADI (n 49) 6. 
a financial institution. The costs for the claims arising from the deposit guarantee system are born by the surviving financial institutions. Research by the European Commission in 2007 shows that 16 Member States are using an ex ante funding system, while six Member States have adopted an ex post scheme. Five deposit guarantee systems do not meet the requirements to be classified either as ex ante or as ex post. These schemes can be categorized under a mixed system. ${ }^{60}$

\section{Economic analysis}

We will now have a look at the deposit insurance system from an economic perspective, taking into account the literature that was reviewed in the second section of this article. The economic analysis will generally address economic effects of explicit deposit guarantee systems and address the way in which the system has been conceived in the EU. Since China does not have an explicit deposit insurance scheme yet, there is little to say on the Chinese system today. The analysis will instead be used to see to what extent China could learn from the way in which Europe has implemented the deposit guarantee scheme.

As we already indicated in the introduction and in the second section, deposit guarantee schemes to some extent pose a kind of paradox. Despite the fact that a deposit guarantee system can contribute to financial stability by making depositor runs less likely, ${ }^{61}$ it can also, ex ante, create adverse incentives for the parties involved. In general, the existence of a deposit guarantee system will lead to moral hazards as the various stakeholders are sheltered from the negative consequences of their behaviour. ${ }^{62}$ Clearly, the more complete the deposit guarantee system, the more likely it is that moral hazards will occur. ${ }^{63}$ We will now analyse more specifically how such a deposit guarantee system could potentially affect the incentives of the various actors.

\section{Incentives of financial institutions}

The existence of a deposit guarantee system can give financial institutions an incentive to pursue more risky investments. ${ }^{64}$ This behaviour is called a moral

60 European Commission, Report on the minimum guarantee level of Deposit Guarantee Schemes Directive 94/19/EC, 2007, 19 (<ec.europa.eu/internal_market/bank/docs/guarantee/report.en. pdf $>$ accessed 27 June 2013). See also European Commission, Joint Research Centre (n 3).

61 Despite the existence of deposit guarantee systems, the current financial crisis shows us that depositors panick and withdraw their money from financial institutions that are in trouble. This behaviour could be seen at Northern Rock in the United Kingdom and Fortis and Dirk Scheringa Beheer in the Netherlands.

62 See generally on this issue, Steven Shavell, 'On Moral Hazard and Insurance' (1979) Q J Econ 541.

63 See, eg, Schich (n 21).

64 Charles AE Goodhart, 'The Regulatory Response to the Financial Crisis' (2009) 46 Centre for Economic Studies IFO Working Paper Series no 2257, <http://ssrn.com/abstract=1113002> accessed 8 May 2013. 
hazard. Moral hazards in banking arise when banks are provided with incentives to take risks, retain the returns, but, at the same time, pass the (potential or realized) costs of the risk to the depositors, regulators, or taxpayers. ${ }^{65}$ In addition, risky financial institutions will often pay higher interest rates to attract funding. We have witnessed this possibility in the case of Icesave, which offered an interest rate of 5.25 per cent compared with an interest rate of 3.4 per cent offered by Rabobank Nederland at the same time. ${ }^{66}$ So it is likely that a deposit guarantee system encourages (excessive) risk taking by insured institutions, leading to a negative impact on their solvency. ${ }^{67}$ However, the way a deposit guarantee system is funded may, to some extent, counterbalance these adverse incentives. Ex ante funding with the use of risk-based premiums can give the participating financial institutions incentives to lower the risk of their operations in order to lower the premiums they have to pay for the deposit guarantee fund. Given the fact that financial institutions are profit-maximizing institutions, they will try to lower their premiums as much as possible in order to maximize their profits. In this way, a risk-based premium will give financial institutions incentives to behave in a less risky way. ${ }^{68}$ Until now, only eight European countries have applied a risk-based contribution to their deposit guarantee fund. The differences have ranged from a minimum contribution of 75 per cent to a maximum contribution of 140 per cent of the standard amount. ${ }^{69}$ One might question whether these differences will give the financial institutions sufficient incentives to lower the risk of their operations.

Looking at the funding of the Dutch deposit guarantee fund, one can notice (i) that the contribution by financial institutions is ex post and (ii) that it depends on the size of their business and not on their risk exposure. ${ }^{70}$ Therefore, it is unlikely that the current deposit insurance system in the Netherlands gives sufficient incentives to the financial institutions for keeping their risk level at an average level. ${ }^{71}$ This means that there has to be a strong supervisory system to encounter the potentially adverse effects of the existing deposit guarantee fund.

65 See AW Mullineux and V Murinde, Handbook of International Banking (Edward Elgar 2003) 640; Groeneveld (n 4) 422.

66 Icesave offered this interest rate in July 2008. See Spaarbaak Euro, <http://www.spaarbaak.nl/ Hogerente.bijnieuwe.Icesave.spaarrekening.txt> accessed 8 May 2013.

67 Santomero (n 18).

68 On the incentives effects of risk differentiation generally, see KJ Crocker and A Snow, "The Theory of Risk Classification' in G Dionne (ed), Handbook of Insurance (Springer 2000) 245. See also Groeneveld (n 4) 422.

69 European Commission (n 60) 2.

70 See Article 12 of the Besluit bijzondere prudentiële maatregelen, beleggerscompensatie en depositogarantie Wft (regulation on preventive measures, compensation for investors and deposit guarantee).

71 There is, moreover, strong empirical evidence showing that the overall effect of a deposit guarantee system is that it induces financial institutions towards excessive risk taking. Hence, it leads to financial instability rather than prevent it. Kam Hon Chu, 'Deposit Insurance and Banking Crisis in the Short and Long Run' (2003) 23 Cato Journal 265. 


\section{Incentives of potential depositors}

The next question is how a deposit guarantee system affects the incentives of potential clients wishing to bring their savings to a financial institution-in short, the depositors. A deposit guarantee system reduces the incentives for depositors to monitor the risks of the financial institutions they are willing to do business with. The reason is that if depositors know ex ante that they are being fully compensated when a financial institution goes bankrupt, it is obvious that they have no incentive at all to look critically at the financial institutions they are willing to do business with. It is likely that they care little about the assets their institutions hold or their likelihood of failure as their claim is on the government, not against the financial institution itself. ${ }^{72}$ The power of this adverse incentive depends on (i) the level and (ii) the structure of the deposit coverage. Within Europe, the level of deposit coverage varies among the member countries, with a minimum level of $€ 50,000$ being stated in the directive of the European Commission. Calculations of the European Commission show that 80 per cent of the savings is already covered at this level. $^{73}$

Besides the level of deposit insurance, the structure of the coverage impacts the incentives for depositors. Some countries implement a certain excess in their deposit coverage. For example, the first layer of, for example, $€ 20,000$ is guaranteed in full, the next layer (of, for example, €80,000) is guaranteed only to a certain proportion of, say 50 per cent. In this way, depositors still face a certain financial risk. This risk should encourage them to monitor the financial institutions they are doing business with more adequately. This mechanism is called co-insurance. However, as already mentioned, the European Commission has abandoned the use of co-insurance in their new Directive 2009/14.

It is important to notice that the earlier-described group of depositors is not the only category of stakeholders in a financial institution. Uninsured depositors, like other creditors, shareholders, and managers, are still exposed to the increased risk exposure of the financial institution. This exposure should encourage them to monitor and limit the riskiness of the bank. ${ }^{74}$ A question one might ask is which party is in the best position to monitor financial institutions. There is, however, a problem in the sense that empirical evidence shows that there is little consumer awareness about deposit insurance. ${ }^{75}$ If there was indeed limited awareness of the deposit insurance scheme, the moral hazard that could follow from such a scheme would probably not be overestimated.

\footnotetext{
Santomero (n 18) 16.

Groeneveld (n 4) 421.

Ibid 420.

75 Michiel Bijlsma and Karen van der Wiel, 'Consumer Perception of Deposit Insurance: Limited Awareness, Limited Effectiveness?' (2012) TILEC Discussion Paper no 2012-013, <http://ssrn. com/abstract $=2034186>$ accessed 8 May 2013.
} 
This recognition shows again exactly the paradox with a deposit guarantee system. A fully coveraging system may dilute incentives for the proper risk management of financial institutions and encourage, in the words of Directive 94/19 'unsound management of credit institutions'. Some incentives should therefore still be provided to potential depositors to monitor the financial institution, of course, assuming that depositors are able to exercise such a monitoring function. In this case, an argument could be made in favour of a so-called co-insurance, meaning that the insurance scheme does not provide full coverage. Another (perhaps more appropriate) alternative would be to introduce risk-based contributions. In the latter case, the manager of the deposit guarantee system would monitor the management of the financial institutions and adapt the contributions to the fund accordingly.

\section{Implicit deposit guarantee system}

Let us, finally, also briefly address the implicit guarantee system since that is in fact the system that currently exists in China. The question arises as to what the effects may be of this nationalization on the incentives for the parties involved. $^{76}$ For the financial institutions, it means that it might encourage recklessness since the government would intervene (for example, by bailing out the company) in the event that it was about to go out of business. It raises the issue of a moral hazard in business operations. When depositors know ex ante that the government is going to bail out large financial institutions whenever they get into trouble, they have little incentive to monitor these institutions themselves due to the fact that they will not face any damage at all in the case of a bail out by the government. ${ }^{77}$ This outcome shows once more the point we also made when discussing the current situation in China in the third section of this article, being that bailing out by government provides worse incentives than a deposit insurance scheme.

\section{Towards a deposit guarantee scheme in China}

The third section of this article showed that China is well on its way to developing a deposit insurance scheme. The fourth section showed the evolution of such a scheme in Europe as well as the problems that it has encountered. The question now arises whether particular lessons can be drawn from the experience in Europe and the economic analysis, given the particular needs of the financial markets in China.

76 On this issue, see also KS Okamoto, 'After the Bailout: Regulating Systemic Moral Hazard' (2009) 57 UCLA L Rev 183, who argues that the financial crisis was caused by what he refers to as 'systemic moral hazard'.

77 T Beck and others, 'Bailing out the Banks: Reconciling Stability and Competition: An Analysis of State-Supported Schemes for Financial Institutions' (2010) 37 Centre for Econ Policy Research, <http://www.cepr.org/pubs/other/bailing.out.the.banks.htm> accessed 6 June 2013. 


\section{Developing a legal and institutional framework}

To some extent, the failure of a financial institution, certainly when it is related to a financial crisis could be compared to a natural disaster. ${ }^{78}$ In some cases (more particularly when a financial crisis is systemic), the probability of its occurrence is difficult to predict and the magnitude of the damage may be huge. $^{79}$ Moreover, many other entities beyond the single financial institution involved could be affected as well. In this respect, one could argue that regulating deposit insurance as a tool to prevent such financial collapse is a public good. Providing and regulating public goods is from an economic perspective the task of government and within the legal framework of the central government. The legislative framework should, as was the case in the EU, focus on the scope of the insured deposits, the insurance method, the deposit insurance agencies, and the legal responsibility of all stakeholders involved. Within the current proposals in China, the State Council will decide the legislative framework instead of the National People's Congress, but according to section 8 of the Legislation Law of the PRC legislating the basic system of social and public policy must be the task of the National People's Congress or its Standing Committee. This would make regulating a legislative framework, which is necessary for a deposit insurance scheme, the task of the National People's Congress.

In addition to choosing an appropriate level to regulate the deposit insurance scheme, it is also important to guarantee the independence of a deposit insurance agency that would be created. Based on the experience in the USA and in Europe, it is of the utmost importance to guarantee that the deposit insurance agency can monitor financial institutions independently and develop the most suitable deposit insurance policies. ${ }^{80}$ Especially within the context of China's financial market, the independence of this agency from other governmental institutions (and, more particularly, from the Ministry of Finance) would be important. Of course, an exchange of information and good cooperation between the deposit insurance agency, on the one hand, and the Central Bank, the Ministry of Finance, and the banking regulatory authorities, on the other hand, is of the utmost importance. However, precisely given the large state involvement in the banking sector ${ }^{81}$ independence of the agency seems of the utmost importance to guarantee the effectiveness of its operations.

78 On the problems with the insurability of natural disasters, see Christophe Courbage and Walter Stahel, 'Insurance and Extreme Events' in Christophe Courbage and Walter Stahel (eds) Extreme Events and Insurance: 2011 Annus Horribilis (Geneva Association 2012) 17-26.

79 On the relationship between financial crisis and insurance, see Michael Faure and Klaus Heine, 'Insurance against Financial Crisis?' (2011) NYU J L \& Business 117.

80 The experience in the USA has also shown that in less strict regulatory regimes and with little supervision by deposit insurance authorities moral hazard (leading to higher risk taking) will pose a serious problem. Grossman (n 39). In this respect, see also White (n 16) who fears that deposit insurance will create insurmountable incentive problems and may therefore be inappropriate for developing or transition economies.

81 Remember that we mentioned that the five largest banks in China are all state controlled. 


\section{The scope of the deposit insurance scheme}

The next question to be regulated in the legislative framework is to which financial institutions the deposit insurance scheme will apply. In this respect, it should be remembered that the situation of the financial market in China is quite a peculiar one, given the role of the top five state-owned commercial banks. Given the state's intervention, they do have a good reputation in the financial market, and, for them, there may not be a need to engage in a deposit insurance scheme, given the fact that they hardly run an insolvency risk. If the deposit insurance scheme was therefore to be voluntary, these top five banks would not be inclined to join the scheme. Given the large volume of their deposits, they would have to pay relatively higher premiums than others. The reluctance of these five big players is probably the most important reason why a mandatory deposit insurance scheme has not yet been introduced in China. ${ }^{82}$

The recent history in China has shown that most of the failed financial institutions have been relatively small- or medium-sized local commercial banks or credit cooperatives. Examples include HDB, ZXUCC, and so on. ${ }^{83}$ For them, the introduction of a deposit insurance scheme is obviously quite important to guarantee depositors' confidence. They would be inclined to join such a scheme (which could also provide protection to the banks), but, given their smaller share in the banking deposit market, the share of premiums they would pay into the insurance fund would be smaller as well.

In order to avoid an unsolvable adverse selection problem (basically meaning that only bad risks would join the scheme), the deposit insurance scheme would have to be universal and mandatory. The scheme should therefore cover the top five state-owned commercial banks, joint-venture commercial banks, city commercial banks, urban credit cooperatives, rural commercial banks, urban and rural cooperative banks, postal savings, and all deposittaking financial institutions.

\section{Coverage level}

The European example has shown that there are a few deficiencies in the European deposit guarantee system, at least as far as providing incentives to the parties involved is concerned. Given the relatively high amount of coverage, there may be negative incentives on the side of the financial institutions,

82 Note that in this respect the situation in China is notably different than at the enactment of federal deposit insurance in the USA. Kane and Wilson show that whereas conventional wisdom held that insurance helped small rural banks at the expense of large urban institutions, data in fact show that the insurance did help stockholders of large banks (more particularly by restoring depositor confidence). Edward J Kane and Barry K Wilson, A Contracting-Theory Interpretation of the Origins of Federal Deposit Insurance' (1998) National Bureau of Economic Research Working Paper no 6451, <http://www.nber.org/papers/w6451>accessed 8 May 2013. Through state ownership, the situation of large banks in China is notably different. 
which have been particularly feared by the European Commission. In this sense, a deposit guarantee system could encourage risky behaviour by the managers of financial institutions. In addition, the incentives for depositors of monitoring the managers of financial institutions would be lacking when the amount of coverage is too high. One obvious remedy is lowering the amount of coverage of the deposit guarantee system. Thus, depositors would still face more risk and, hence, have more incentive to monitor the financial institutions they are doing business with.

Furthermore, a lower coverage level would also have a positive effect on the incentives of financial institutions. It is likely that a lower coverage level would result in less moral hazard and therefore in less risky activities by financial institutions. Lowering the coverage level would also imply shifting the balance from the deposit guarantee system to the use of tort law. The chance that a depositor is not fully compensated by the deposit guarantee system increases when the coverage level decreases. Therefore, it is likely that depositors would use tort law more often (by holding the financial regulators or government liable) in order to get compensation. As a result, both the government and financial regulators would face a greater risk of being held liable and, as a result, would have more incentive to keep a close watch on the behaviour of financial institutions. Thus, lowering the coverage level of the deposit guarantee fund would obviously be the best solution for improving the incentives for all parties involved. Of course, one has to be careful with this remedy, particularly in the context of China. If the coverage level is so low that many deposits would not be covered anymore under the insurance scheme, the system would totally lose its effectiveness.

Another method, also discussed and proposed in the literature in Europe, ${ }^{84}$ is to introduce co-insurance (sometimes also referred to as a deductible). This method would mean that a lower threshold would have to be passed, for example, and depositors would hence still carry part of the risk themselves. Again, both remedies (lowering the coverage level and introducing co-insurance) might be proposed in the EU context (where depositors may not need savings to satisfy their basic needs), but they may be risky in the context of China. If, after all, the deposit insurance scheme would provide amounts of coverage that are too low, the risk of bank runs (which is the main motivation to start the deposit insurance scheme in the first place) could not be eliminated. Hence, the question arises whether, notwithstanding the deposit insurance scheme, appropriate incentives to managers could not be provided via other techniques.

\section{Financing}

In most countries, the contribution due by the financial institution to the insurance fund is simply linked to the number of deposits. Hence, this quantity

84 See, eg, Dijkstra and Faure (n 5) 156-73. 
has amounted to applying a single uniform rate to the contributions. With the development of financial innovation activities, high-risk banking business has increased, and, as a result, a single uniform rate deposit insurance scheme could not meet the reality of banking development. Thus, multiple rates for different bank-risk levels are more suitable for the current situation. Charging a risk-based contribution has therefore become possible with the new tools of financial risk management. Charging risk-based contributions would obviously provide better incentives to financial institutions and could therefore remedy the risk that the deposit insurance scheme would provide for unsound management. There may be arguments for such a risk-based contribution scheme in China as well. For example, it could be held that the insolvency risk posed by the top five banks is probably considerably lower, given their reinforcement by the government. Moreover, charging a lower deposit insurance rate might attract them to join a newly established deposit insurance scheme.

Both single and multiple rate systems are based on the actuarial calculation of deposit insurance premiums, the insolvency probability of commercial banks, and deposit insurance funds' interests. However, whereas in the EU and the USA financial risk management has developed to such an extent that charging risk-based premiums is possible, ${ }^{85}$ the risk assessment system in China's financial institutions does not seem to have matured to such a level that it would be possible to develop a detailed system of risk-based contributions. In addition, the deposit insurance agency is still to be installed, and its staff has to accumulate enough experience to be able to charge differentiated contributions. Initially, the main goal for the newly established deposit insurance scheme would be to change from the implicit (government provided) to the explicit deposit insurance scheme. The first priority may therefore be to develop an appropriate organizational and institutional framework.

One could therefore hold that in an initial phase it may be more appropriate (notwithstanding the economic advantages of a risk-based contribution system) to start the Chinese deposit insurance scheme with unified or fixed fees. In this respect, one should also remember that creating risk-based contributions may create specific problems in China. For example, it would inevitably lead to lower rates for the top five banks with their excellent reputation and to higher rates for local commercial banks. The result would be that the public may suspect that higher insurance rates would reflect higher risks as a result of which depositors could transfer money from the higher rate (local) banks to the low-risk (state-owned) banks, which would obviously be an unwanted result. Hence, one could consider the financing system in China in the light of the fact that the privatization and decentralization of the commercial banking system in China has not yet been completed. Charging

85 Interestingly, the USA learned from the failure of the Federal Savings and Loan Insurance Corporation (which was in crisis in early 1989) that risk dependent premiums had to be charged. Before this time, federal insurers largely charged uniform premiums that ignored risk, thereby insufficiently controlling for moral hazard. Lawrence J White, 'The Reform of Federal Deposit Insurance' (1989) 3 J Econ Perspectives 11. 
risk-based contributions in an initial stage may thus lead to the undesirable result of supporting the state-owned enterprises to the disadvantage of the other players. Therefore, we argue that, differently than in the EU, it may be more appropriate in China to start a system with unified contributions. Such a system would benefit small- and medium-sized commercial banks, which could compete more appropriately with the larger state-owned banks. When deregulation and privatization in the banking sector in China has reached a later stage, introducing risk-based premiums could be considered.

\section{The timing}

A legislative act may be symbolic for the explicit establishment of a deposit insurance scheme. Based on international experience, there is now a fairly large consensus in China concerning the benefits of the introduction of such a scheme. Discussions, however, still need to take place on the optimal timing. The US deposit insurance scheme was established after the Great Depression, ${ }^{86}$ but many other countries (such as Canada) established a deposit insurance scheme during a peaceful period. The question of the optimal timing for the introduction of the deposit insurance scheme in China has led to heated discussions, especially after the financial crisis. There are two different points of view among scholars on the timing issue. Wei Jianing, vice-director of the Macroeconomic Research Department in the State Council Development Research Center, argues that China should speed up the establishment of a deposit insurance scheme to prevent possible bank runs in the future. $^{87}$ While Wang Guogang, president of the Institute of Finance and Banking in the Chinese Academy of Social Sciences, has argued that since there is a lack of a supporting system of interest marketization, increasing deposit insurance rates, and no independent insurance supervision body, a hasty introduction of a deposit insurance scheme may actually be harmful to China's financial stability and security. ${ }^{88}$

We have argued that the introduction of a deposit insurance scheme is an important element in a sound financial infrastructure. We have also argued that given the stable macro-economic conditions in China, the timing for the introduction of such a scheme in China has matured. Hence, there seem to be very few reasons to further delay the introduction of such a scheme in China.

86 For the history of the deposit insurance legislation of 1933 in the USA, see Carter H Golembe, 'The Deposit Insurance Legislation of 1933: An Examination of Its Antecedents and Its Purposes' (1960) 75 Pol Science Q 181; White (n 16). See also Charles W Calomiris and Eugene M White, 'The Origins of Federal Deposit Insurance' in Claudio Golden and Gary D Libecap (eds), The Regulated Economy: A Historical Approach to Political Economy (University of Chicago Press 1994) 145-88.

87 Jianing Wei and Jiaolong Jiang, 'Speeding up the Establishment of a Deposit Insurance Scheme in China' (2009) 16 China Finance 46 [in Chinese].

88 Guogang Wang, 'Introduction of a Deposit Insurance System Should Not Be Too Hasty' (2007) 7 Studies Int'l Finance 59 [in Chinese]. 


\section{Concluding remarks}

This article began by arguing that China has experienced quite a few cases of bank runs and subsequent bank failures. Some new commercial financial institutions have emerged and, in fact, have already collapsed a few years later. To a large extent, these incidents are now covered through an implicit insurance system that basically consists of the government bailing out financial institutions. Given the (still) important role that the government (both the central state as well as local authorities) plays in China's financial system, it provides implicit insurance when financial institutions in which it has a stake collapse. However, this article has also shown with examples that this system is becoming increasingly costly. Moreover, many banks in China are no longer state owned or are only owned by local authorities, and some commercial banks are entering the financial market as well. However, the fact that they may not rely on such an implicit insurance system may create unequal conditions of competition since the implicit insurance system (provided by the public authorities) could be considered to be state aid. Now that China has, with the Anti-Monopoly Law of the PRC, introduced the importance of competition within its market system, it seems important that, as far as financial institutions are concerned, this distortive effect should be remedied. ${ }^{89}$ An explicit deposit insurance scheme, so we have argued earlier, may provide such a remedy.

Experiences in the USA and in Europe have shown that a deposit insurance scheme can indeed provide this protection to depositors and may therefore contribute to the prevention of bank runs. ${ }^{90}$ China has seen various attempts to introduce an explicit deposit insurance scheme as well, but the system is currently on hold as a result of the financial crisis. It is feared that the introduction of such a scheme in these times of financial turmoil will lead to financial instability. We argue that it is nevertheless important to introduce such a scheme in China, precisely to provide financial stability. However, we equally argue that the institutional design needs to take into account the particular features of the financial market in China as a result of which solutions that may have worked in the USA or in Europe cannot simply be copy and pasted to China. For example, the fact that the big five state-owned banks still play such an important role in China's financial system may be quite important in the institutional design. In addition, from an economic perspective (and based on experience in Europe), one would normally advise a differentiation whereby risk dependent contributions are charged.

89 Anti-Monopoly Law of the People's Republic of China (30 August 2007). For an evaluation of the anti-monopoly law in China, see the contributions in Faure and Zhang (n 1).

90 Although the 2008 financial crisis showed that the system may not have been perfect. After all, Europe already had a deposit insurance scheme that could apparently not prevent bank runs in particular cases, which was the reason to increase the amount of coverage in the new directive of 2009 (see the discussion earlier in this article). 
However, this scheme may be a dangerous route to go in China. Such a risk differentiation would probably lead to higher contributions for smaller commercial banks than for the big five banks, which can all count on an implicit guarantee by the state. Such risk differentiation could provide a wrong signal to the market that the smaller commercial banks that are entering the market may be less reliable than the state banks, which would jeopardize the privatization of the banking system in China. This potential outcome may be an argument in favour of introducing a flat rate premium, at least when the deposit insurance scheme is introduced. Obviously, it will require some political goodwill on the side of the big five state banks, which will then (at least in this first phase) cross-subsidize to some extent the smaller commercial banks. Another issue that needs to be carefully designed is the precise definition of the optimal amount of the deposit insurance scheme. Experiences from the USA and Europe have taught that this amount needs to be carefully balanced - not too high, on the one hand (thus stimulating a moral hazard on the side of the depositors) and, on the other hand, not too low (in order to prevent bank runs).

Of course, these and other institutional design issues need to be carefully addressed when introducing a deposit insurance scheme in China. In the newest attempt to introduce interest marketization to attract deposits, which began on 8 June 2012, even the top five banks raised their interest rate higher than the standard 7.7 per cent, while the other smaller banks raised their rate to a ceiling of 10 per cent. ${ }^{91}$ With this interest marketization, there must be a market-wise deposit insurance scheme as the mating system. This kind of phenomenon indicates that there are important points that can undoubtedly be further addressed in our future research.

91 Rongping Hu, 'Who Will Be the Winner of Interest Marketization?' (2012) Economic Observer $<$ http://finance.sina.com.cn/review/hgds/20120615/235412327827.shtml> accessed 8 May 2013 [in Chinese]. 